\title{
Development of an Adjustable Rake-Type Sugarcane Piler ${ }^{1}$
}

\author{
Tom S. Chisholm²
}

\begin{abstract}
The rapid mechanization of sugarcane harvesting in Puerto Rico has become necessary in recent years because of steadily decreasing availability of manual labor. The $\mathrm{V}$-cutter harvester, popularly known as la Coneja, has been used extensively in Puerto Rico. This harvester produces a windrow which is difficult to load effectively with the conventional pile-and-grab loaders commonly used in Puerto Rico. A rake-type sugarcane piler with tines individually adjustable vertically was developed to utilize the existing loaders more effectively. This piler normally is mounted on a pile-and-grab loader. The loader transfers previously cut cane from field windrows to transport carts pulled beside the loader. Eight of these adjustable pilers have been fabricated thus far and successfully used in harvesting more than 200,000 tons of cane.
\end{abstract}

\section{INTRODUCTION}

In Puerto Rico approximately 150,000 acres are devoted to sugarcane production. The above-ground portion of the mature sugarcane crop consists basically of mature stalks, immature tops and leaves. In the harvest of sugarcane, the stalks must be gathered in the field and transferred to a mill where they can be processed to extract the sugar.

Until the last few years, almost all of the cane in Puerto Rico was cut and windrowed manually. Some of this hand-cut cane also was loaded manually into transport carts but most was loaded mechanically. Once in carts, it could then be transported to the mill. A common practice when cutting by hand was for a man to cut and top four to six rows of cane and place it in a single windrow to span the furrow between rows and perpendicular to the direction of the rows. A windrow of this type can be handled readily by a loading machine which moves along parallel to the rows. The usual loading practice involves a piler mounted on the front of the loader. The purpose of the piler is to push-pile a sufficient amount of cane in front of the loader so that a hand-like grab is able to pick it up from this pile. For this type of windrow, in which the canes are

${ }^{1}$ Manuscript submitted to Editorial Board April 2, 1975.

${ }^{2}$ Formerly Assistant Agricultural Engineer, Department of Agricultural Engineering, Agricultural Experiment Station, Mayagüez Campus, University of Puerto Rico, Río Piedras, P.R. 
perpendicular to the direction of travel of the loader, a 2-pointed piler as shown in figure 1 can be used effectively.

A number of mechanical harvesting systems have been tried in Puerto Rico. Some of them involve a windrow similar to the hand-cut type. These windrows can be loaded readily with conventional equipment.

One cutting machine which has received widespread use, however, produces a different type of windrow. The $V$-cutter popularly known as "la Coneja" produces a 2-row windrow in which the canes are not perpendicular to the rows; instead, the canes are positioned at various angles more nearly parallel to the rows. The cane windrow is located between two of the original cane rows. The $\mathrm{V}$-cutter is shown in figure 2. The orientation of cane stalks in the $\mathrm{V}$-cutter windrow causes 2-pointed pilers to operate ineffectively. Some of the canes tend to slide through the piler resulting in excessive amounts of cane left in the field. Experience has shown that amounts of cane in excess of 10 tons/acre are often left in the field after the initial loading.

This left-over cane is manually gathered sometimes as a separate operation known as scrapping. If permanently positioned tines are added on the piler in an attempt to reduce cane loss, another problem develops. Because the depth and spacing of the ridge-and-furrow configurations usually vary from one field to another, these tines cannot be depended upon to fit the ridge-and-furrow configurations in different fields.

\section{MATERIALS AND METHODS}

In view of the general problem described, the following functional design requirement was established: Improve upon the effectiveness of existing equipment for working in the $\mathrm{V}$-cutter windrow to reduce the amount of cane left in the field, without gathering excessive amounts of soil with the loaded cane. At the same time the equipment developed should be equally effective in the other types of windrows.

An experimental prototype, somewhat similar to the unit shown in figure 3 was designed, built, and field tested with a view to meet the established functional requirements.

The piler is mounted on the loader so that it pivots at the end of the two arms extending back to the loader. A lift chain from the loader supplies any necessary vertical force which is not provided by the floating action of the piler.

This experimental unit comprised two tines with float-shoes and four tines without shoes. Some of the tine points were is in thick and some were 1 in thick. The float-shoes and thin tine points were intended to minimize picking up soil with the cane. Each tine could be individually adjusted vertically, and the tines could be positioned at various locations transversely along the tool bar to provide different spacings between 
tines. These two types of adjustments were varied to achieve minimal field loss under a wide variety of operating conditions. Many modifications of the float-shoes were tried, but the shoes either dug into the ground or rode up over the cane, and thus the shoes were removed. It was found that under most field conditions, however, considerable floating action could be obtained from the bottom surfaces of the tine points.

In testing the experimental piler it was observed that some cane moved sideways and was lost around the ends of the piler. To counteract this effect, the two tines with wings shown in figure 4 were incorporated into the unit.

By trying various horizontal tine spacings under different field conditions, it was found that a spacing of about $11^{3}+$ in between tines worked reasonably well and the tine spacing was permanently fixed at this value in the later design of the commercial type piler.

It was found frequently necessary to adjust the individual tines vertically as the loader moved from one field to another. An adjustment device was incorporated, therefore, which allowed this to be done quickly and without tools. This device basically includes a 1-in-diameter adjusting pin, a ${ }^{1} / 2$-in-diameter locking pin, and a $2 \times 2 \times 1_{2}^{1}$ in locking block as shown in figure 5 . The locking block is welded permanently to the tine holder. The locking pin has a small projection which matches an indexing slot in the hole through the adjusting pin and the hole through the locking block. These holes with slot are easily made by drilling two different size holes off-center from one another. At the left side of figure 5, the 1-indiameter adjusting pins and the 1/2-in-diameter locking pins are seen lying on the concrete slab. In the center of the photograph an adjusting pin and a locking pin are shown installed in the tine holder, with the locking pin extending through the locking blocks. The locking pin has to be rotated $180^{\circ}$ for removal. The adjusting pin can then be removed and the tine can be slid up or down in the tine holder as required. The $1^{1}: 2$-indiameter pipe extending below the locking block is to protect the locking pin. The tine shank has adjustment holes spaced 3 in apart and the tine holder has adjustment holes spaced 2 in apart, making it possible to obtain increments of 1 -in vertical adjustment of the tine. Seven more commercial type pilers have subsequently been used for one harvest season and some have been used for two harvest seasons. These pilers have operated satisfactorily in the mechanical harvest of over 200,000 tons of cane.

Data were gathered to evaluate the performance of the adjustable piler as compared with the performance of two different types of pilers which have been in general use. 


\section{RESULTS AND DISCUSSION}

Table 1 summarizes the results by giving the amount of cane left in the field after the initial loading. The amount of cane left in the field was divided into loose cane and cane attached to the stool. the at tached cane represents a loss that can be properly assigned to the cutting function rather than the loading function. Cutting was performed with the V-cutter.

There are a number of other factors besides the piler type which influence the amount of loose cane left in the field by the loader. Some of these factors are: operator care and skill. cane variety (susceptibility to shattering), and presence of cross-ditches and other non-uniformities in the field. Based on field data and personal observations, it was concluded that under favorable loading conditions the adjustable piler can reduce the amount of loose cane left in the field to approximately 3 tons/acre;

TaBc: 1.-Cane left in the field (tons/acre) for three types of pilers

\begin{tabular}{lccc}
\hline \multicolumn{1}{c}{ Piler type } & Loose & Attached & Total \\
\hline Adjustable & 4.23 & 1.22 & 5.45 \\
Standard 2-pointed & 9.42 & 2.14 & 11.56 \\
Wide 4-pointed & 9.59 & 1.94 & 11.53 \\
\hline
\end{tabular}

under more adverse loading conditions the amount of loose cane left in the field can be reduced to approximately 5 tons/acre.

The adjustable sugarcane piler weighs about 1,000 Ib and can be mounted on either a wheel-type or a track-type loader. It performance on the track-type loader is better if long mounting arms are extended back near the center of the loader as shown in figure $6 .^{3}$

The experimental piler was used during the major part of a harvest season with about 10,000 tons of cane. It was mounted on different types of loaders and used under a wide variety of field conditions.

\section{RESUMEN}

Durante lns últimos años se ha hecho necesario mecanizar aceleradamente la recolección de la cosecha de caña de azúcar en Puerto Rico a causa de la menguante disponibilidad de obreros agrícolas. El uso de la cortadora en " $V$ ". popularmente conocida con el nombre de "La Coneja", se ha extendido en poco tiempo en Puerto Rico. Esta cortadora forma una hilera de caña amontonada que resulta dif́cil de cargar eficazmente con las cargadoras corrientes que se usan en Puerto Rico. El objetivo primordial de esta

3'Specifications for a Rake-type Sugarcane Piler with. Tines that are Individually Adjustable Vertically" can be obtained by writing to the Department of Agricultural Engineering, University of Puerto Rico, Mayagüez, Puerto Rico 00708. 
investigación fue desarrollar una apiladora que fuera capaz de apilar eficazmente les enmarañadas hileras de caña amontonada tal como hace la cortadora en " $V$ ", y que a la vez disminuyera a un mínimo el contenido de materia extraña. Además, se tuvo en mente que la máquina a desarrollarse pudiera funcionar igualmente bien en las hileras de caña características de los sistemas de corte manual y de las cortadoras "de tipo soldado." Tales objetivos se lograron satisfactoriamente y como resultado, ya se han puesto en uso con mucho éxito unas ocho unidades de este tipo de rastrillo apilador con los que se han apilado más de 200,000 toneladas de caña.

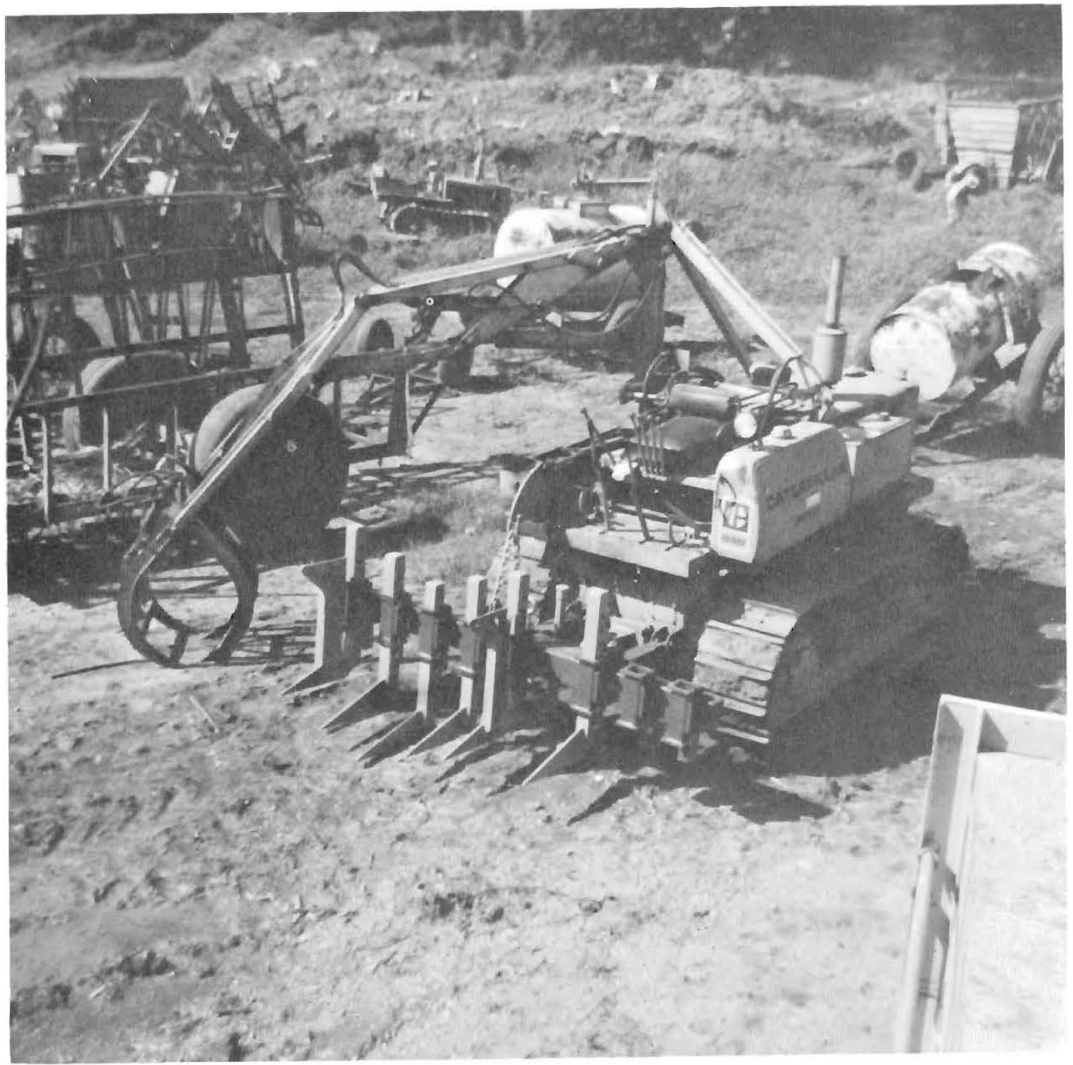

FIc. 1.-The adjustable rake-type sugarcane piler mounted on a conventional pile-andgrab loader. 


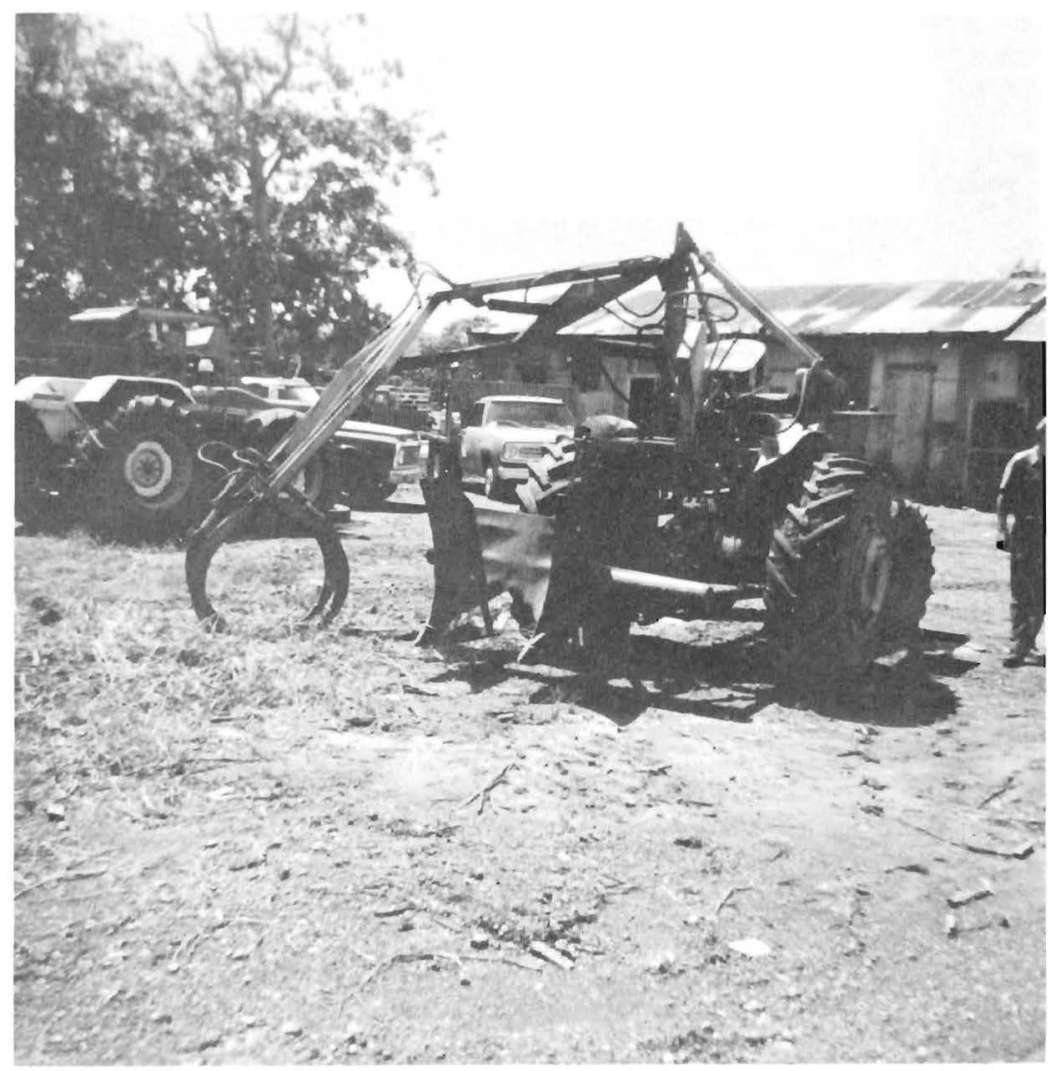

FIC. 2.-A conventional 2-pointed piler as currently used with hand-cut and manually windrowed cane. 


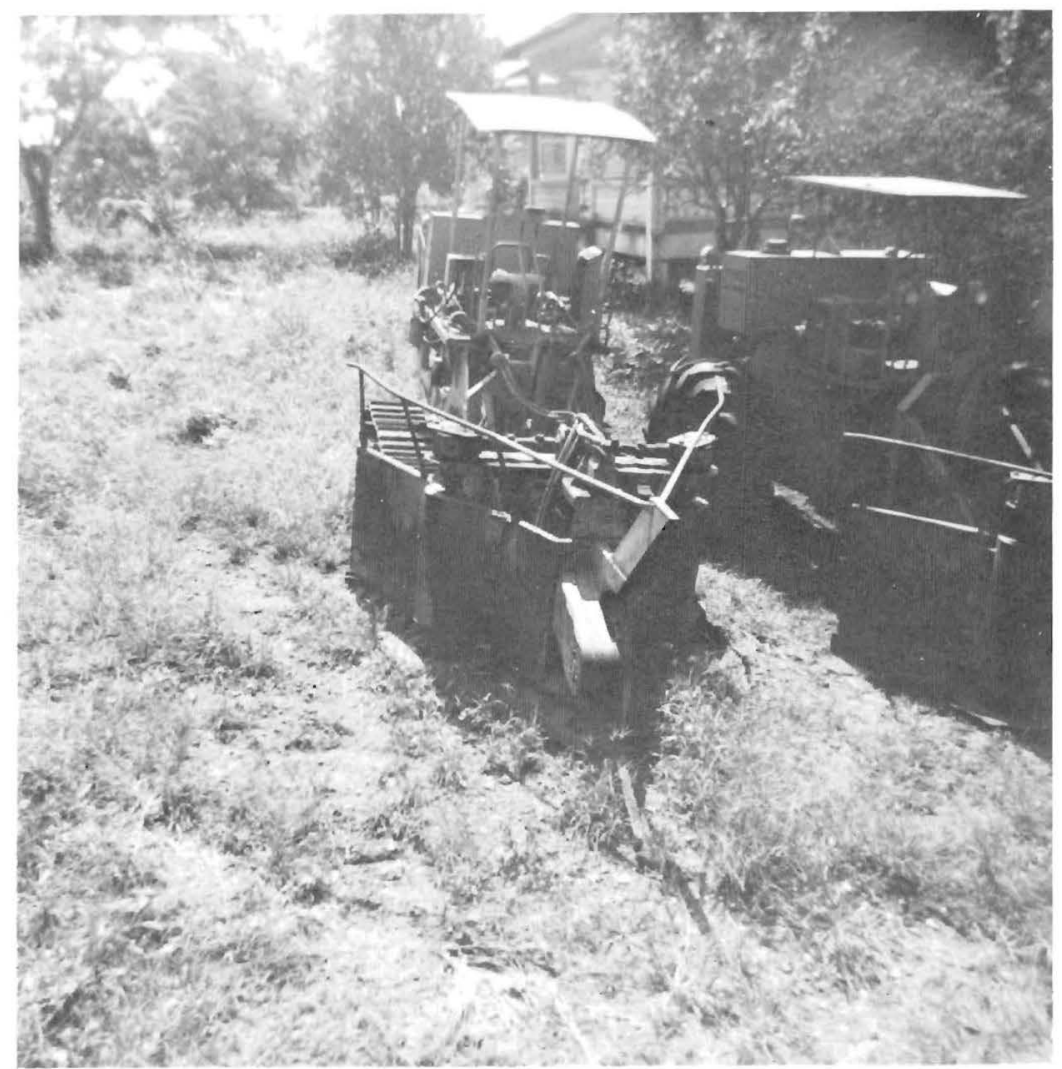

Fir. 3.-View of the V-cutter popularly known in Puerto Rico by the name of "La Coneja". 


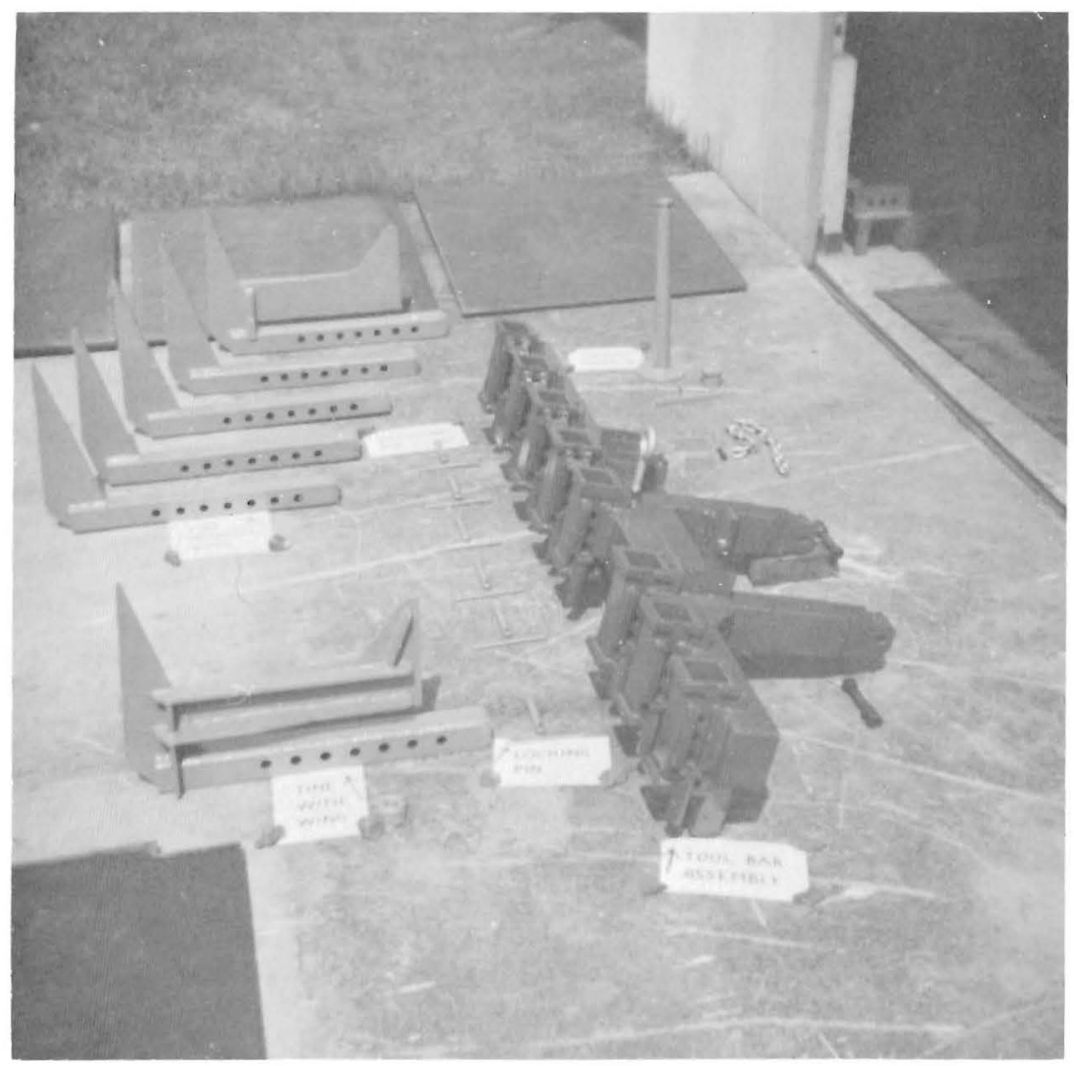

Frr. 4.-Exploded view of the experimental prototype showing the tool bar assembly, the adjustable tines, and the adjusting and locking pins. 


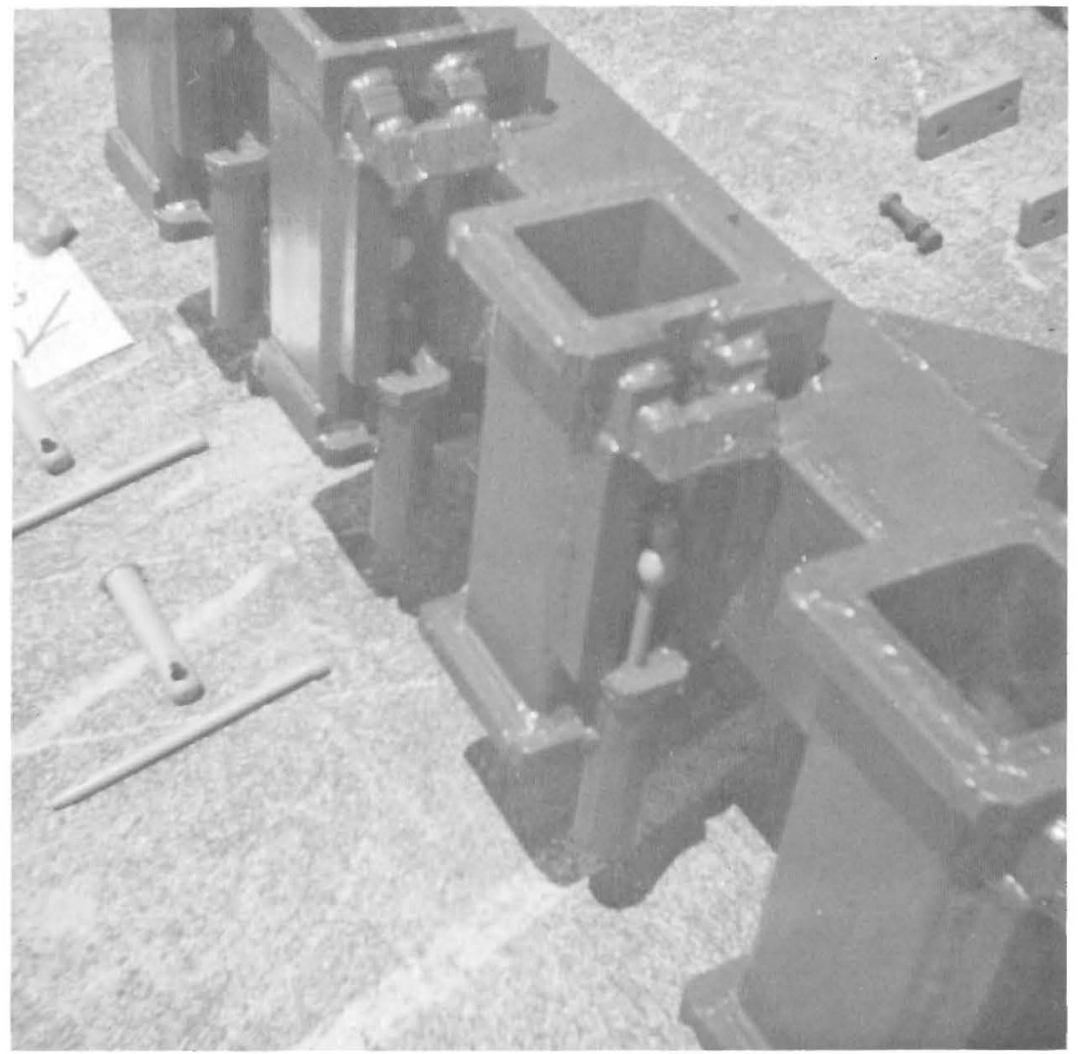

FIG. 5.-Close-up view of the holders showing the construction and components of the adjusting device. 


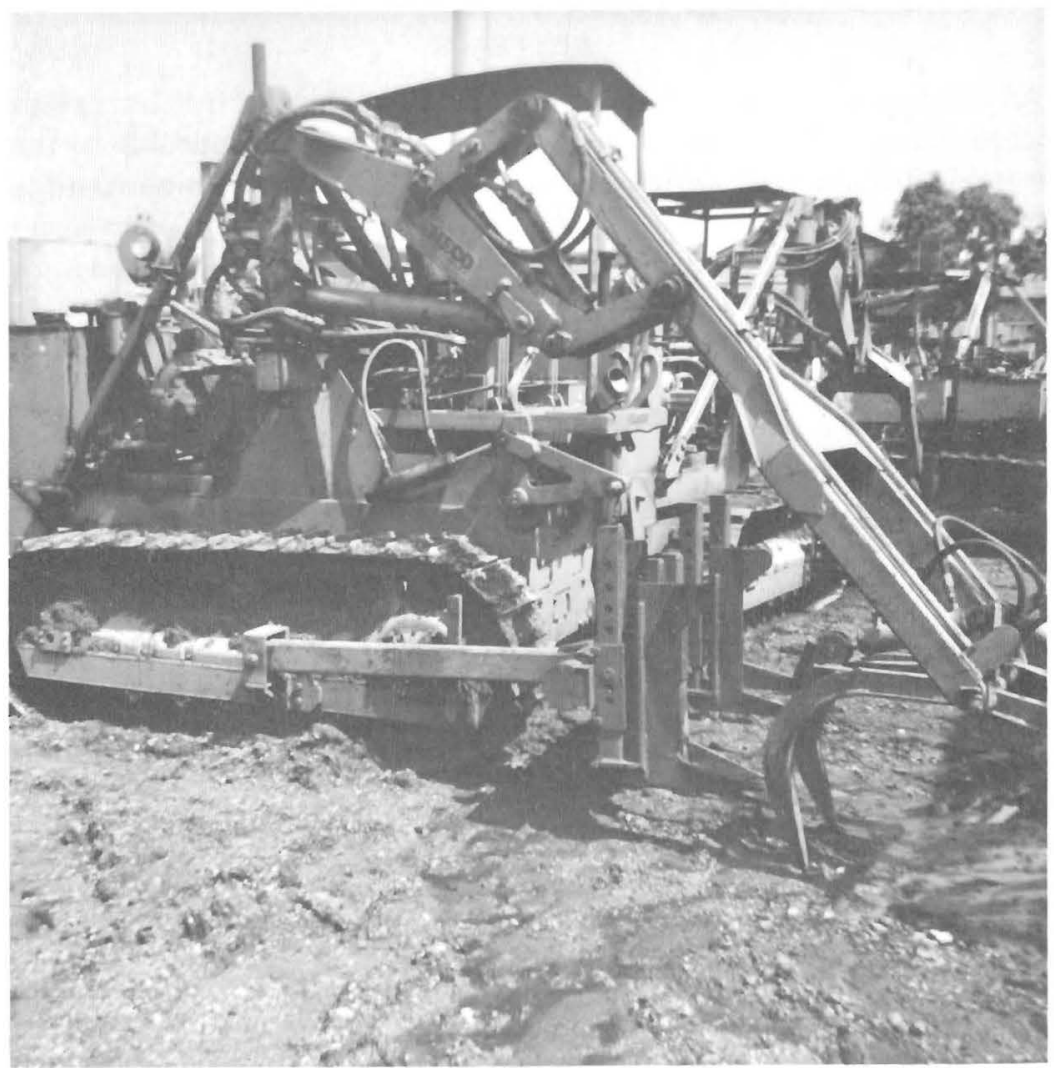

FIG. 6.- The adjustable sugarcane piler mounted on a track-type loader. 